\title{
Effect of hydrothermal treatment temperature on morphology of obtained calcium silicate from rice husk ash
}

- Pham Trung Kien ${ }^{1}$ - Email: phamtrungkien@hcmut.edu.vn

- Tran Pham Quang Nguyen ${ }^{1}$

- Nguyen Hoc Thang ${ }^{2}$

${ }^{1}$ Faculty of Materials Engineering, Ho Chi Minh City University of Technology, VNU-HCM.

${ }^{2}$ Faculty of Chemical Technology, Ho Chi Minh City University of Food Industry.

(Manuscript Received on July, 2016, Manuscript Revised on September, 2016)

\begin{abstract}
This research report on the effect of hydrothermal treatment temperature on morphology of obtained calcium silicate from Vietnam Rice Husk Ash (VRHA). VRHA is collected at the Mekong Delta River, burn to obtain the active silica which can be used for further step. The obtained silica is hydrothermal treated in the present of Ca-source so that the $\mathrm{Ca} / \mathrm{Si}$ molar ratio of 1.0 for different treatment

XRD and SEM of samples before and after hydrothermal treatment confirm the present of nano-Calcium Silicate Hydrate (CSH) such as Tobermorite and Xonotlite. These CSH can be used as inorganic light weight thermal insulator application. The obtained calcium silicate after hydrothermal treatment at high temperature have leave-like crystal, and these crystal interlock together.
\end{abstract} temperature such as 110, 130, 150 and $1800 \mathrm{C}$.

Keywords: Hydrothermal, rice hush ash, calcium silicate, environmental materials

\section{INTRODUCTION}

Vietnam is an agriculture producing country, in which produce lot of rice and its by product is rice husk ash (RHA). The RHA is consider as waste of agriculture industry, and treated by burn in the open air. This process cause air pollution, thus attracted researcher to find alternative method to reduce the impact of rice husk ash to environment [1-3]. The research group in Department of Ceramic Materials aim to reuse rice husk ash as source of Silica $\left(\mathrm{SiO}_{2}\right)$ [4-5]. Our research group successful to synthesize the rice hush ash using hydrothermal treatment method [6-8]. However, the effect of hydrothermal treatment method on crystal morphology is still unknown. In this research, the effect of hydrothermal treatment temperature on the morphology of obtained calcium silicate was reported.

\section{MATERIALS AND METHODS}

\subsection{Prepation of sample}

Rice husk was burn at $500^{\circ} \mathrm{C}$ at the heating rate of $10^{\circ} \mathrm{C} / \mathrm{min}$ (Naberthem 1400 , Nabertherm, Germany), then soaking at 2 hour for complete burning. The phase composition of obtained 
VRHA was characterized using X-ray Diffraction (XRD) and Fourier transform infrared spectroscopy (FTIR). The chemical composition of RHA was analyzed using X-Ray Fluorescent (XRF) method. In addition, $\mathrm{CaO}$ was used from the commercial without further purified (Xilong Chemical, China). The phase composition of commercialized $\mathrm{CaO}$ was comfirmed using XRD. The mixture of RHA and $\mathrm{CaO}$ was mixed with the $\mathrm{Ca} / \mathrm{P}$ molar ratio of 1.0 with the moisture of $10 \%$ (weight percent) then pressing at $30 \mathrm{MPa}$ to form the compacted disk with diameter of $9 \mathrm{~mm}$. The compacted disk was hydrothermal treated at $110^{\circ} \mathrm{C}, 130^{\circ} \mathrm{C}$, $150^{\circ} \mathrm{C}$ and $180^{\circ} \mathrm{C}$ for 24 hours to obtain $\mathrm{CSH}$ mineral.

2.2. Characterization of sample before and after hydrothermal treatment

\subsubsection{Phase analysis:}

The powder Xray Diffraction (XRD) patterns of disk samples were recorded with a vertically mounted diffractometer system (Bruker-AXS: D8 ADVANCE, Germany) using $\mathrm{Ni}$ filtered CuKa generated at $15 \mathrm{kV}$.

\subsubsection{Inspection the morphology of samples using Scanning Electron Microscope (SEM):}

The surface of samples was observed using a scanning electron microscope (SEM) (JSM 5400LV, JEOL Co. Ltd., Japan) under an accelerating voltage of $20 \mathrm{kV}$ after being coated with gold.

\subsubsection{Chemical bonding of sample:}

The samples were mixed with $\mathrm{KBr}$ with the ratio 1: 200 and analyzed using Fourier Transform Infrared (FTIR) method with the waveband vary from $400-4000 \mathrm{~cm}^{-1}$.

\subsubsection{Chemical composition of sample:}

The sample is energied using $\mathrm{X}$-ray Fluoresence (XRF) (MESA-50, Horiba, Japan) and measure the secondary beam to analyze the chemical composition of sample.

\subsubsection{Bulk density:}

The bulk density of sample is measured using the weight and volume ratio of sample $(\mathrm{n}=6)$, and is expressed by mean \pm standard deviation. ANOVA analysis to use for statistical analysis.

\section{RESULS AND DISCUSSION}

The chemical composition of RHA is given in Table 1.

Table 1. Chemical composition of RHA (weight percentage)

\begin{tabular}{|l|l|}
\hline Oxide & \multicolumn{1}{|c|}{ Weight \% } \\
\hline $\mathrm{SiO}_{2}$ & 92.7 \\
\hline $\mathrm{K}_{2} \mathrm{O}$ & 3.16 \\
\hline $\mathrm{CaO}$ & 1.33 \\
\hline $\mathrm{P}_{2} \mathrm{O}_{5}$ & 0.59 \\
\hline Other & 1.59 \\
\hline
\end{tabular}

This data indicates that dominant oxide in RHA is silica (>92\%) Therefore RHA can be used as source of qualified silica for the next experiment in order to turn RHA from trash to treasured materials.

The phase analysis of RHA is also given in Figure 1, indicating that RHA is composed of low degree of crystallinity crystolbalite according to PDF card \#39-1425. 
In addition, the FTIR spectrum of RHA is given in Figure 2, indicated that the main chemical bonding of RHA is O-Si-O, and these data go well with XRD data given in Figure 1

The phase analysis of $\mathrm{CaO}$ is given in Figure 3, indicating that commercialized $\mathrm{CaO}$ is pure and can be used for further reaction.

The phase analyses of compacted disk before and after hydrothermal treatment at $110^{\circ} \mathrm{C}, 130^{\circ} \mathrm{C}, 150^{\circ} \mathrm{C}$ and $180^{\circ} \mathrm{C}$ for 24 hours.

Before hydrothermal treatment, the phase composition of sample is low degree of crystobalite and $\mathrm{Ca}(\mathrm{OH})_{2}$. The present of $\mathrm{Ca}(\mathrm{OH})_{2}$ is formed by hydration of $\mathrm{CaO}$ and water during the mixing process. After hydrothermal treatment, the new phase of Calcium Silicate Hydrate (CSH), Tobermorite (T) and Xonotlite $(\mathrm{X})$ sre observed.

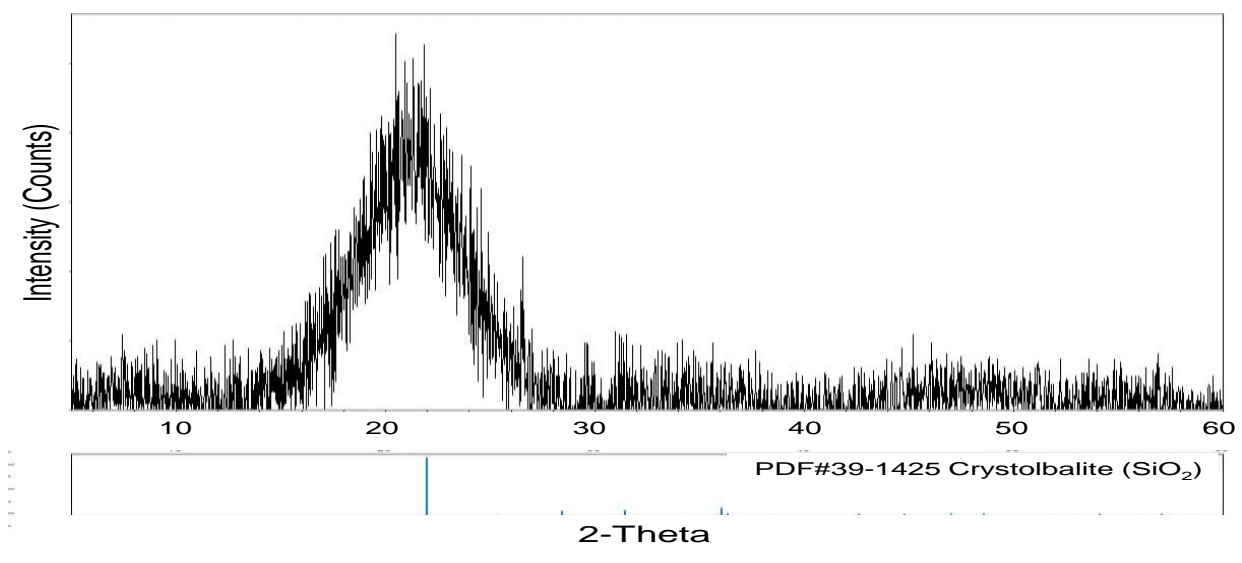

Figure 1. XRD pattern of RHA

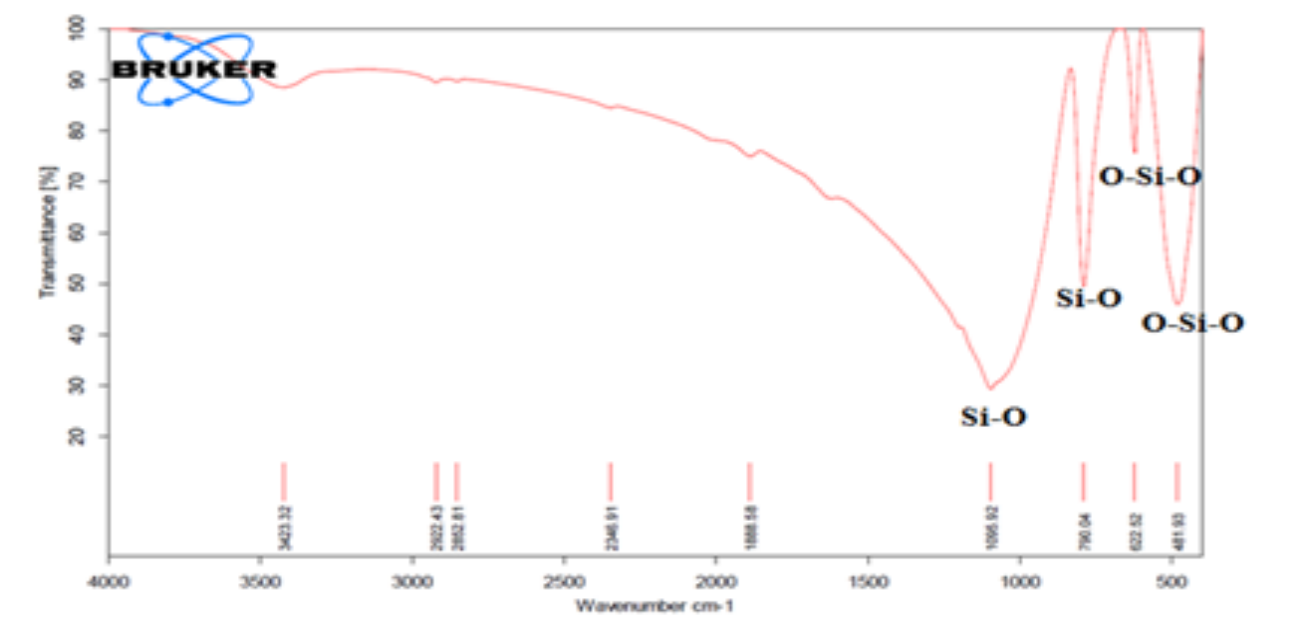

Figure 2. FTIR spectrum of RHA 


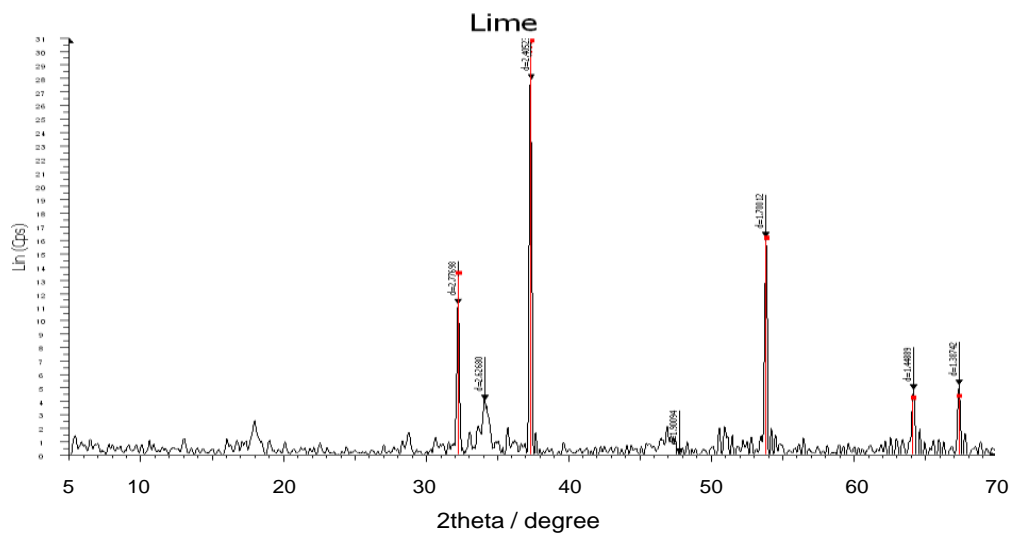

Figure 3. XRD pattern of commercialized $\mathrm{CaO}$.

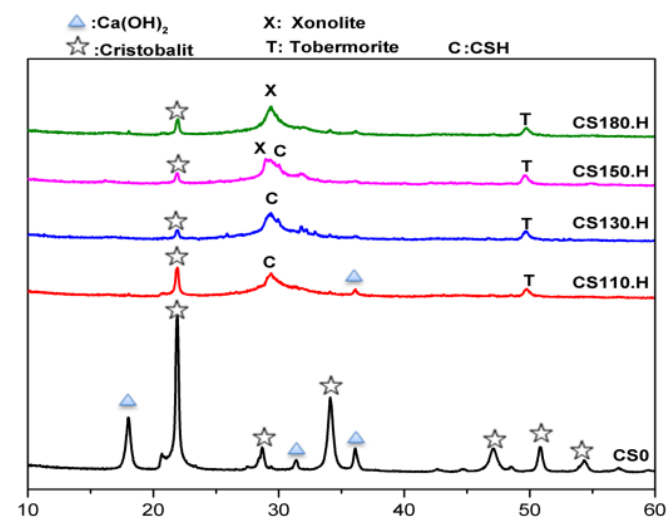

Figure 4. XRD patterns of compacted disk before and after hydrothermal treatment at various temperature: (a) before; (b) $110^{\circ} \mathrm{C}$; (c) $130^{\circ} \mathrm{C}$; (d) $150^{\circ} \mathrm{C}$ and (e) $180^{\circ} \mathrm{C}$

The morphology of sample before and after hydrothermal treatment at $110^{\circ} \mathrm{C}, 130^{\circ} \mathrm{C}, 150^{\circ} \mathrm{C}$ and $180^{\circ} \mathrm{C}$ for 24 hours also is given at Figure 5.
We can observed the morphology changes of sample before and after hydrothermal treatment with the increase of hydrothermal treatment temperature. At $150^{\circ} \mathrm{C}$ and $180^{\circ} \mathrm{C}$, the new pore can be observed, while the morphology transitionally changing from polyonal-like shape (black arrow in Figure 5a, b and c) to leave-like shape (white arrow) and these leave-like shape crystals are interlocked together (Figure $5 \mathrm{~d}$ and e). The size of new leave-like shape also increased with the increasing of hydrothermal treatment temperature (Figure 5d and e).

\section{Trang 72}



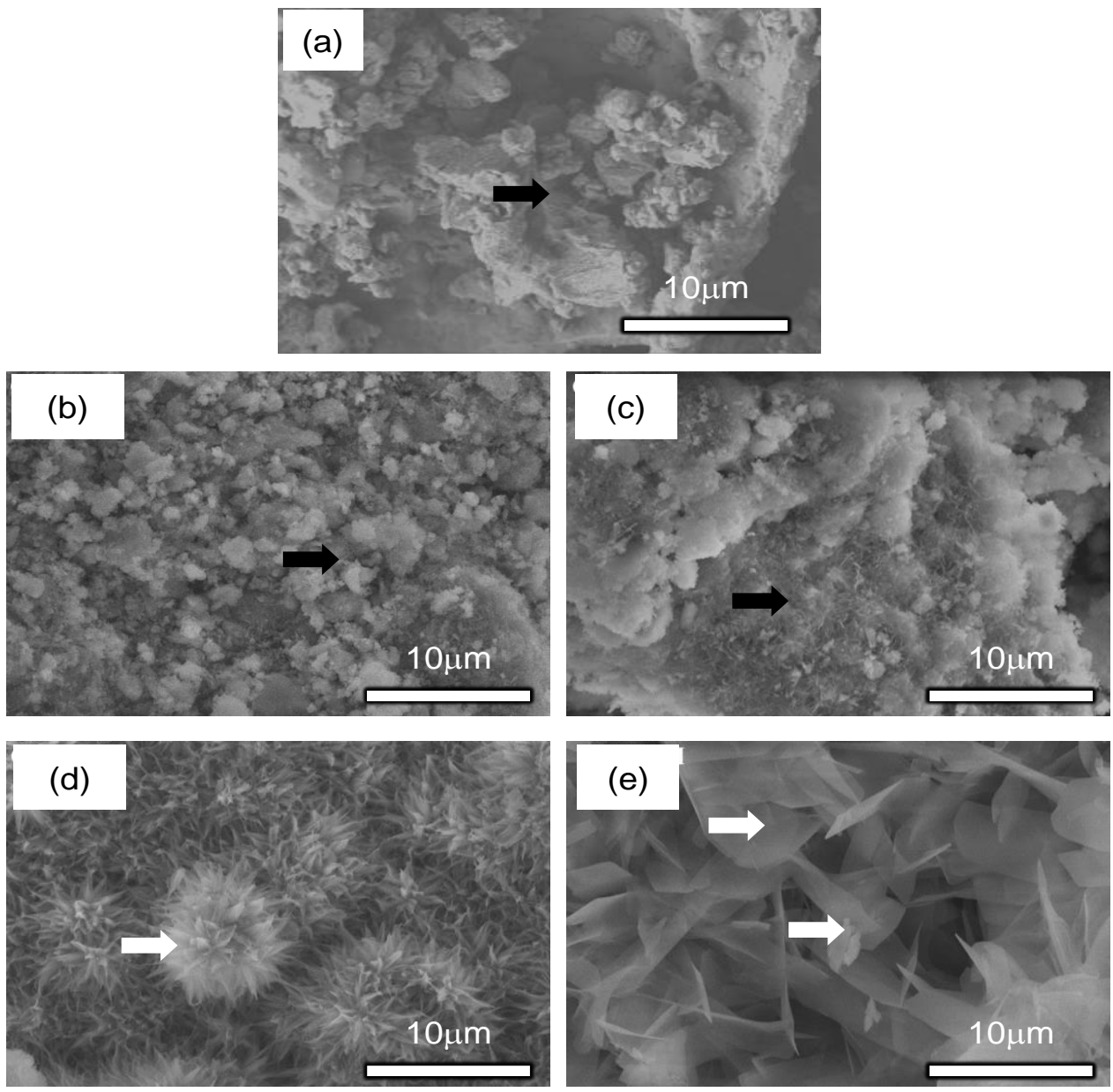

Figure 5. SEM images of sample before and after hydrothermal treatment at different temperature: (a) before; (b) $110^{\circ} \mathrm{C}$; (c) $130^{\circ} \mathrm{C}$; (d) $150^{\circ} \mathrm{C}$ and (e) $180^{\circ} \mathrm{C}$.

The bulk density of sample before and after hydrothermal treatment is also given in Figure 6. The bulk density decrease with the increase of hydrothermal treatment temperature, and go well with the increase the number of pores in Figure $5 \mathrm{~d}$ and $5 \mathrm{e}$.

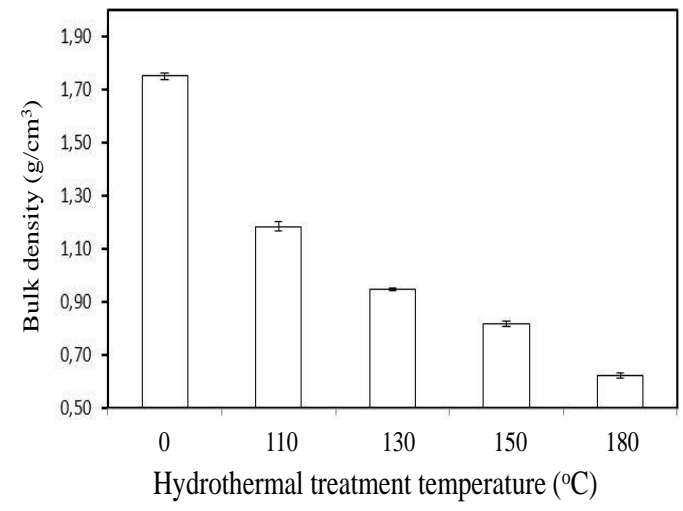

Figure 6. Bulk density of sample before and after hydrothermal treatment at different temperatures. 


\section{CONCLUSIONS}

By using hydrothermal treatment technique, the mixture of $\mathrm{RHA} / \mathrm{CaO}$ can be converted into Calcium Silicate Hydrate, Tobermorite and Xonotlite which can be used as inorganic thermal insulator. The effect of higher hydrothermal treatment temperature can accelerate the forming of leave-like crystals. The new product have very low bulk density (around $0.6 \mathrm{~kg} / \mathrm{cm}^{3}$ ) compare with before hydrothermal treatment $(1.75$ $\mathrm{kg} / \mathrm{cm}^{3}$ ), thus can be used as light weight inorganic thermal insulator. Further research on effect of hydrothermal treatment temperature is carried out to obtain the understanding on hydrothermal treatment technique on RHA.

Acknowledgment: "This research is funded by Vietnam National University Ho Chi Minh City University of Technology (VNU-HCMUT) under grant number C-2016-20-28”.

\section{Ảnh hưởng chế độ hấp thủy nhiệt lên hình thái học của khoáng Calcium Silicate từ tro trấu}

- Phạm Trung Kiên

- Trần Phạm Quang Nguyên

- Nguyễn Học Thắng

Trường Đại học Bách Khoa, ĐHQG-HCM

Trường Đại học Công nghiệp TP.HCM

\section{TÓM TẮT}

Bài báo trình bày nghiên cưu ảnh huoơng nhiệt độ hấp thủy nhiệt lên hình thái học của khoáng calcium silcate tù̀ tro trấu Việt Nam được lấy tù khu vực đồng bằng sông Cưu Long, dốt để tạo silica hoạt tính. Silica thu được được hấp thủy nhiệt với Ca theo tỉ lệ mol Ca/Si 1.0 ơ 
các khoảng nhiệt độ khác nhau nhu 110, 130, 150 và $180^{\circ} \mathrm{C}$. XRD và SEM của mẫu hấp thủy nhiệt xác nhận tạo thành khoáng nano-Calcium Silicate Hydrate (CSH) nhu Tobermorite,
Xonotlite, và úng dụng nhu vật liệu cách nhiệt nhẹ Khoáng calcium silicate sau hấp thủy nhiệt có tinh thể hình lá, và đan xen lẫn nhau.

Tù khóa: Hâp thủy nhiệt, tro trấu, calcium silicate, vật liệu môi truoòng.

\section{REFERENCES}

[1]. Tiggemann MH, Tomacheski D, Celso F, Ribeiro VF, Nachtigall SMB. Use of wollastonite in a thermoplastic elastomer composition. Polymer Testing, 2013; 13731378..

[2]. Soliman AM, Nehdi NL. Effects of shrinkage reducing admixture and wollastonite microfiber on early-age behavior of ultra-high performance concrete. Cement \& Concrete Composites, vol, 46,2014; 81-89.

[3]. Saadaldin S, Rizkalla A. Synthesis and characterization of wollastonite glassceramics for dental implant applications. Dental materials, vol. 30, 2014; 364-371.

[4]. Pham TK, Nguyen HT, Do QM, Do MH, Gallardo SM, Bacani FT, Hirofumi H, Michael AB. Properties and microstructure of geopolymer from red mud, rice husk ash and diatomite. Journal of Science and Technology, vol. 53 (2B), 2015; 215-221.

[5]. Michael AB , Nguyen HT, Pham TK, Hirofumi H, Florinda TB, Susan MG.
Optimizing Ternary-blended Geopolymers with Multi-response Surface Analysis. Waste and Biomass Valorization, vol. 7(29), 2016; 1-11.

[6]. Pham TK, Kieu DTK, Do QM, Nguyen HT, Ly HA, Pham TTT. Research on wasted glass as non-firing brick using hydrothermal method. Journal of Science and Technology, vol. 52(4A), 2014; 198204.

[7]. Pham TK, Do MH, Nguyen HT, Pham TLT. Innovation to recycle SiO2-sourced solid waste in Glass and Rice Ash Industry and Society. The 8th Regional Conference on Chemical Engineering in conjunction with The 7th Vietnam National Chemical Congress and The 2nd Vietnam National Chemical Engineering Congress. Ha Noi, Vietnam. 29 Nov - 01 Dec 2015, pp. 304305.

[8]. Pham TK. Ability to use wasted cullet in glass industry as environmental-friendly materials for sustainable development. RCME 29-30 Oct 2015, Bangkok, section 1C-3, pp. 1. 